\title{
CREATE ENVIRONMENTAL CONDITIONS FOR SUGAR BEET PRODUCTION BY ADDING BIO AND ORGANIC FERTILIZER UNDER NEWLY RECLAIMED SALINE SOIL IN NORTH SINAI. \\ Wafaa A. Hafez \\ Soils, Water and Environment Research Institute, Agric. Res. Centre Giza, (Egypt).
}

\begin{abstract}
Two field experiments were conducted in Galbana village, North Sinai Governorate during two winter seasons 2011/2012 and 2012/2013, to evaluate the environmental effect of mineral nitrogen fertilizer rate, compost and bio-fertilizer on some soil properties and sugar beet productivity under newly reclaimed saline soil. The seeds of sugar beet (Beta vulgaris) variety Loil were inoculated with Rhizobium radiobacter strain (salt tolerant PGPR). Results indicated that the soil pH was not significant as affected by bio-fertilizer or compost alone or in combination with different rates of mineral nitrogen fertilizer. The soil salinity decreased with increasing rate of mineral nitrogen combined with bio-fertilizer or compost. The relative increases of soil available $\mathrm{N}$ content in soil due to mineral nitrogen fertilizer; compost and biofertilizer after sugar beet cultivation, followed the descending order: bio-fertilizer> compost > mineral $\mathrm{N}$ as compared with initial soil for available $\mathrm{N}$ content. The relative increases in both $\mathrm{P}$ and $\mathrm{K}$ followed the descending order: compost $>$ bio-fertilizer $>$ mineral $\mathrm{N}$ fertilizer as compared with soil initial contents of $\mathrm{P}$ and $\mathrm{K}$. The available micronutrients ie $\mathrm{Fe}, \mathrm{Mn}$, and $\mathrm{Zn}$ in soil were not significantly affected by the different fertilization treatments in both the first and second seasons. Also, available Fe was not significantly affected with rate of the used fertilizers whereas the effects of different rates on the available contents of both $\mathrm{Mn}$ and $\mathrm{Zn}$ were significant in the second season, however in the first one such rates were of significant effect of $\mathrm{Zn}$ only. The interactions among bio-fertilizer, compost and mineral nitrogen rates were of significant effects on Mn content in soil in both seasons whereas such an effect was significant on $\mathrm{Fe}$ in both seasons and $\mathrm{Mn}$ in the first one. The highest mean values of fresh and dry root yield, sugar yield, total soluble solids (TSS), purity and sucrose were achieved due to treating soil with bio-fertilizer together with the mineral nitrogen fertilizer. The highest values of $\mathrm{N}(1.14 \%)$ concentration in root was observed at soil treated with compost plus $100 \mathrm{~kg}$ mineral $\mathrm{N}$ fertilizer, while the maximum values of $\mathrm{P}$ and $\mathrm{K}$ concentration $(0.28 \%$ for $\mathrm{P}$ and $1.29 \%$ for $\mathrm{K}$ ) was observed as affected by bio-fertilizer plus $100 \mathrm{~kg}$ mineral $\mathrm{N}$, respectively. On the other hand, the effect of all treatments tested on $\mathrm{Fe}, \mathrm{Mn}$ and $\mathrm{Zn}$ concentration in root of sugar beet was non significant. As a conclusion, bio-fertilizer and compost application in sugar beet could increase characteristics of sugar beet root and reduced consumption of mineral nitrogen fertilizer and successfully reduced the hazard effect of soil salinity condition.

Keywords:Soil salinity; bio-fertilizer; compost; mineral nitrogen; sugar beet productivity.
\end{abstract}

\section{INTRODUCTION}

Bio-fertilizers are applied to reduce the use of mineral fertilizers and supports an effective and environmentally safe tool for desert development 
beside of decreasing agricultural costs and at the same time maximizing crop yield. Also, biofertilization provides plant with some nutritive elements and growth promoting substances (Arafa et al. 2009). Bassal et al. (2001) recorded that inoculation of sugar beet seeds with Azotobacterin significantly increased TSS $\%$, sucrose $\%$, and purity $\%$ and root as well as sugar yields/fed. Ramadan et al. (2003) showed that biofertilization had a significant effect on root, top and sugar yields/fad ${ }^{-1}$. but on the other hand, exhibited insignificantly effect on sucrose \% and purity \%. Calderon et al. (2004) found that the urea fertilizer application was of slightly alkaline effect on soil $\mathrm{pH}$. EL-Geddawy et al. (2001) found that levels of nitrogen (60, 80 and $100 \mathrm{~kg} \mathrm{~N}$ $\mathrm{fed}^{-1}$ ) had no statistical differences with relation to total soluble solids (TSS) $\%$, sucrose \%, root and sugar yields fed-1 of sugar beet. Mousa (2004) observed that, nitrogen fertilizer sources such as ammonium nitrate had a significant effect on the parameters of growth of sugar beet but each of ammonium nitrate and urea gave the highest sugar yield with non significant differences between them. Selim et al. (2010) found that increasing application rate of $\mathrm{N}$ increased fresh weights of roots and shoots, sugar yield and juice purity as compared with the control treatment. Nitrogen fertilization of sugar beet crop can be used as a bioremediation mean of sodic soils through removing high $\mathrm{Na}$ ions especially at the high applied doses of $\mathrm{N}$ fertilization. Fathy et al. (2009) reported that the effect of application of mineral $\mathrm{N}$ fertilizer on the roots and foliage fresh and dry weights and sugar yield of sugar beat significantly increased with increasing $\mathrm{N}$ fertilizer rates over two seasons.

Organic matter is known to improve soil health and availability of plant nutrients, (Guillaumes et al., 2006). Compost results in suppression of pathogens and improvement in the C:N ratio, and is easy to handle, store, transport and apply in soil compared with non-composted organic residues, (Hachicha et al., 2006). Helmy et al. (2013) suggested that the application of compost $+179 \mathrm{~kg} \mathrm{~N} \mathrm{ha}^{-1}$ caused soil $\mathrm{pH}$ to decrease probably due to the effect of microorganisms on decomposing organic matter and hence releasing organic acids. Tandon (2000) found that physical properties (hydraulic conductivity, bulk density and total porosity) of salt affected soil greatly improved when compost was applied. Siam et al. (2013) indicated that lowest of soil EC was obtained by $100 \mathrm{~kg} \mathrm{~N} / \mathrm{fed}$ as urea combined with compost in the both seasons. Sherif et al. (2012) indicated that the applying organic matter significantly increased the availability of $\mathrm{N}, \mathrm{P}, \mathrm{K}, \mathrm{Fe}, \mathrm{Mn}$ and $\mathrm{Zn}$ in soil as compared with control. These results may be due to the chelating effect of the organic components on the nutritive metal ions that keeps them in an available form. Shaban et al. (2011) suggested that the amount soil available nutrients $\mathrm{N}, \mathrm{P}$ and $\mathrm{K}\left(\mathrm{mgkg}^{-1}\right.$ soil) increased with increasing rates of compost in combination with applied mineral $\mathrm{N}$ at a rate of $\left(120 \mathrm{~kg} \mathrm{~N} \mathrm{fed}^{-1}\right)$. Likewise, available micronutrients $\mathrm{Fe}, \mathrm{Mn}$, and $\mathrm{Zn}\left(\mathrm{mgkg}^{-1}\right.$ soil) increased when compost and organic manure were combined with different mineral $\mathrm{N}$ - fertilizer levels. Sarwar et al. (2008) reported that the combined application of both organic and inorganic fertilizers improved chemical properties of soil and enriched the fertility status of soil. Negm et al. (2003) indicated that adding organic manure increased soil productivity and 
available contents of micronutrients (i.e, $\mathrm{Fe}, \mathrm{Mn}, \mathrm{Zn}$ and $\mathrm{Cu}$ ), in some newly reclaimed soils. Mohamed et al. (2008) found that the addition of organic manure increased crop productivity as a result of increasing soil bioavailability of micronutrients (i.e, $\mathrm{Fe}, \mathrm{Mn}, \mathrm{Zn}$ and $\mathrm{Cu}$ ) and cation exchange capacity as well as improving most of the physical properties in the newly reclaimed soils.

The current study aims at:-

1. Evaluating the effects of some environmental friendly products such as compost, and biofertilizer on alleviating the negative effects of salinity conditions.

2. Evaluating the effects of compost and bio-fertilizer in combination with mineral nitrogen fertilizer at different rates on yield and its components of sugar beet grown on a newly reclaimed saline soil.

3. Rationalization of using nitrogen fertilizer to reduce pollution resulting from the extra use of these fertilizers.

4. Reducing the high cost of buying inorganic fertilizers and maintaining the long term productivity of soils for sustainable agriculture.

\section{MATERIALS AND METHODS}

A field experiment was carried out at the Sahl El-Tina, North Sinai Governorate, during the two winter successive seasons of 2011/2012 and 2012/2013, to study the efficiency of used bio-or compost fertilization combined with mineral nitrogen at different rates on soil fertility and sugar beet (Beta vulgaris, variety Loil) productivity and quality under saline soil conditions.Some physical and chemical properties of the investigated soil are presented in Table (1).

Table (1). Some Physical and chemical properties of the experimental soil.

\begin{tabular}{|c|c|c|c|c|c|c|c|c|c|}
\hline \multicolumn{7}{|c|}{ Particle size distribution } & \multirow{2}{*}{\multicolumn{2}{|c|}{$\begin{array}{l}\text { O.M. } \\
\mathrm{g} \mathrm{kg}^{-1}\end{array}$}} & \multirow[b]{2}{*}{$\begin{array}{c}\mathrm{CaCO}_{3} \\
\mathrm{~g} \mathrm{~kg}^{-1}\end{array}$} \\
\hline $\begin{array}{c}\text { Coarse } \\
\text { sand (\%) }\end{array}$ & $\begin{array}{l}\text { Fine } \\
\text { sand } \\
(\%)\end{array}$ & Silt (\%) & \multicolumn{2}{|c|}{ Clay (\%) } & \multicolumn{2}{|c|}{$\begin{array}{c}\text { Textural } \\
\text { class }\end{array}$} & & & \\
\hline 7.44 & 68.44 & 9.60 & \multicolumn{2}{|c|}{14.52} & \multicolumn{2}{|c|}{ Sandy clay } & \multicolumn{2}{|l|}{4.1} & 78.5 \\
\hline \multirow{2}{*}{$\mathrm{pH}(1: 2.5)$} & \multirow{2}{*}{$\begin{array}{c}\mathrm{EC} \\
(\mathrm{dS} / \mathrm{m})\end{array}$} & \multicolumn{5}{|c|}{ Cations (m molel $\left.{ }^{-1}\right)$} & \multicolumn{3}{|c|}{ Anions (m molel ${ }^{-1}$ ) } \\
\hline & & $\mathrm{Ca}^{++}$ & $\mathrm{Mg}^{++}$ & $\mathrm{N}$ & & $\mathrm{K}^{+}$ & $\mathrm{HCO}_{3}^{-}$ & $\mathrm{Cl}^{-}$ & $\mathrm{SO}_{4}^{--}$ \\
\hline 8.11 & 13.42 & 10.58 & 21.13 & 10 & & 0.90 & 10.00 & 90 & 34.20 \\
\hline \multicolumn{3}{|c|}{ Available Macronutrients (mg/kg) } & \multicolumn{7}{|c|}{ Available Micronutrients $(\mathrm{mg} / \mathrm{kg})$} \\
\hline $\mathrm{N}$ & $\mathrm{P}$ & $\mathrm{K}$ & $\mathrm{Fe}$ & & $\mathrm{Mn}$ & $\mathrm{Zn}$ & & & \\
\hline 30 & 3.10 & 186 & 2.13 & & 1.45 & 0.72 & & & \\
\hline
\end{tabular}

Soil tillage:

Soil surface was leveled using laser technique. Deep sub-soiling plough, and establishment of field drains at a distance of $10 \mathrm{~m}$ between each of two drains at a depth of $90 \mathrm{~cm}$ at the drain beginning, establishment of an irrigation canal in the middle part of the experimental plot unit were carried out. The plot units were subjected to continuous and alternative leaching processes before sugar beet planting. Compost was added 25 days before 
sugar beet transplanting at a rate of 5 ton $^{-1}{ }^{-1}$.The chemical properties of the used compost shown in Table (2). The compost analyses were done according to the standard methods described by Brunner and Wasmer (1978).

Table (2). Chemical properties of the used compost.

\begin{tabular}{|c|c|c|c|c|c|c|c|c|c|c|c|}
\hline \multirow{2}{*}{$\begin{array}{c}\text { Moisture } \\
\text { content \% }\end{array}$} & \multirow{2}{*}{$\begin{array}{c}\text { (1: } \mathrm{dSm}^{-1} \\
(1:\end{array}$} & $\begin{array}{c}\mathrm{pH} \\
(1: 2.5)\end{array}$ & $\mathrm{C}$ & $\mathrm{C} / \mathrm{N}$ & $\mathrm{O} . \mathrm{M}$ & $\mathrm{N}$ & $\mathrm{P}$ & $\mathrm{K}$ & Fe & Mn & Zn \\
\cline { 3 - 11 } & & \multicolumn{8}{|c|}{$(\%)$} \\
\hline 20.25 & 2.35 & 7.65 & 29 & 10.10 & 35 & 2.87 & 0.73 & 1.57 & 215 & 120 & 94 \\
\hline
\end{tabular}

Seeds were inoculated with Rhizobium radiobacter strain (salt tolerant PGPR) biofertilizer isolated from the rhizosphere soil of Sahl El-Tina and deposited in the Gen bank under number of HQ395610 Egypt by Biofertilizer Production Unit, Department of Microbiology, Soils, Water and Environment Research Institute, Agricultural Research Center, Giza, Egypt. The inoculated grain plots were soil applied with liquid bacteria strain three times after 21, 42 and 62 days from planting as described by Shaban and Omar (2006). The experimental design was a randomized complete block with three replicates.

Sugar beet seeds were hand sown using one side of the ridge in hills $25 \mathrm{~cm}$ apart at a rate of 3-5 seeds /hill during the first and second seasons. Plants were thinned at the age of 35 days from planting leaving one plant/hill. The seeds were sown on October $10^{\text {th }}$ and $15^{\text {th }}$ for the first and second seasons, respectively. The area of each plot was $50 \mathrm{~m}^{2}(10 \mathrm{~m}$ lengths $X 5 \mathrm{~m}$ width). Nitrogen fertilizer as urea $(46 \% \mathrm{~N})$ was added at a rate of $(0,50,75$ or $100 \mathrm{~kg} \mathrm{~N} \mathrm{fed}^{-1}$ ) in three equal doses just after thinning and then 45 and 60 days later. Potassium sulphate $\left(48 \% \mathrm{~K}_{2} \mathrm{O}\right)$ at a rate of $75 \mathrm{~K}_{2} \mathrm{O} \mathrm{kg}$ was applied in two doses after 21 and 50 days from sowing. Calcium super phosphate $\left(15.5 \% \mathrm{P}_{2} \mathrm{O}_{5}\right)$ was applied at a rate of $200 \mathrm{~kg} \mathrm{fed}^{-1}$ during preparation.

Soil analysis:

A surface soil sample $(0-30 \mathrm{~cm})$ was collected, air - dried, sieved to pass through a $2 \mathrm{~mm}$ sieve and mixed thoroughly. Calcium carbonate, organic matter, total soluble ions and electrical conductivity (EC) were determined in the saturated soil paste extract while the $\mathrm{pH}$ was measured using a $\mathrm{pH}$ meter in soil suspension (1: 2.5) as described by Page et al. (1982). Available nitrogen was measured according to the modified Kjeldahal method by Black, (1965). Available phosphorous, potassium and micronutrients (Fe, $\mathrm{Mn}$, and $\mathrm{Zn}$ ) were extracted using ammonium bicarbonate (DTPA) as described by Soltanpour (1985) and determined using Inductively Coupued Plasma (ICP) Spectrometry model 400.

Plant analysis: At harvest, ten plants were sampled randomly from each plot. The roots were separated, dried at $70 \mathrm{C}^{\circ}$ for three days to determine their dry weight. Dry root samples were ground digested using $\mathrm{H}_{2} \mathrm{SO}_{4}$ and $\mathrm{HClO}_{4}$ acid mixture according to the method described by Black, (1965). then plant contents of $\mathrm{N}, \mathrm{P}, \mathrm{K}, \mathrm{Fe}, \mathrm{Mn}$ and $\mathrm{Zn}$ were determined in the plant digests using the methods described by Cottenie et al. (1982). Sucrose was 
determined according to the method of Le-Docte (1927).Total soluble solids (TSS) were measured in juice of fresh roots by using a Hand Refractometer.

Sugar yield ( $\mathrm{t} / \mathrm{fad}$ ) was calculated by multiplying dray root yield by sucrose percentage. All data were statistically analyzed for least significant difference as described by Snedecor and cochran (1979).

\section{RESULTS AND DISCUSSIONS}

\section{Soil chemical properties}

Soil pH.

Data in Table (3) show that the soil pH was not significantly affected by the studied treatments in the two growing seasons, however, it was decreased to lower values due to application of compost combined with 75 and $100 \mathrm{~kg} \mathrm{~N} \mathrm{fed}^{-1}$ than the other treatments did. These results are in agreement with those of Aguilera et al. (2012) who found that the addition of organic or inorganic fertilizers slightly decreased soil $\mathrm{pH}$. The soils of all the experimental plots were of moderately alkaline $\mathrm{pH}$ ranging from 7.96 to 8.09. Such decreases in soil $\mathrm{pH}$ can be attributed to the effect of nitrification process from basic ( ammonium) form to mildly acidic (nitrate) form through the activity of the nitrifying bacteria in soil Nasef et al. (2009). The reduction of soil $\mathrm{pH}$ may be attributed to the production of organic acids resulted from the microbial activity Rashad et al. (2006). The reducing effect of bio-fertilizer combined with mineral nitrogen on soil $\mathrm{pH}$ from 8.06 to 7.98 might be attributed to associated increase in activity of dehydrogenase enzyme as well as the release of carbon dioxide in the rhizosphere due to exhalation of the microorganisms Shaban and Omar (2006).

\section{Soil salinity:}

Data in Table (3) reveal that a significant effect was shown due to the different rates of applied mineral nitrogen on decreasing the soil salinity, while non of the fertilization treatments could significantly effect the soil salinity. The combination of bio-fertilizer or compost with mineral nitrogen fertilizer was of significant effect on decreasing of soil salinity. The corresponding relative decreases in mean values of soil salinity $\left(\mathrm{EC} \mathrm{dSm}{ }^{-1}\right)$ were 36.36 and $42.25 \%$ in the first and second seasons for soil treated with the mineral nitrogen, 40.01 and $50.07 \%$ in first and second seasons for soil treated with the compost and 41.21 and $51.19 \%$ in the first and second seasons for soil treated with the bio-fertilizer compared with soil initial.

These results are in agreement with those obtained by Nasef et al. (2009) who indicated that application of bio and organic fertilizers combined with different mineral nitrogen fertilizer levels decreased soil salinity probably because the bio- fertilizer and compost could improve the soil physical properties (increasing soil porosity). and consequently enhanced leaching process through irrigation fractions. Bio-fertilizers promote plant growth and reduced the salinity stress. Abd El-All et al. (2013) and Ali et al. (2014) reported that application of biofertilizer slightly decreased the soil EC compared with the control. Rifat (2010) reported that the reduction in soil salinity might be attributed to the activity effect of microorganisms on 
improving soil structure and increasing drainable pores and consequently enhanced leaching process.

Table (3). Soil pH, EC and macronutrients contents in the studied soil after harvesting of the sugar beat.

\begin{tabular}{|c|c|c|c|c|c|c|c|c|c|c|c|}
\hline \multirow[t]{2}{*}{ Treatment } & \multirow{2}{*}{$\underset{\text { kgfed- }^{1}}{\mathbf{N}}$} & \multirow{2}{*}{\multicolumn{2}{|c|}{$\begin{array}{c}\mathrm{pH} \\
(1: 2.5)\end{array}$}} & \multirow{2}{*}{\multicolumn{2}{|c|}{$\begin{array}{c}E C \\
\left(\mathrm{dSm} m^{-1}\right)\end{array}$}} & \multicolumn{6}{|c|}{$\begin{array}{c}\text { Available macronutrients } \\
\left(\mathrm{mg} \mathrm{kg}^{-1}\right)\end{array}$} \\
\hline & & & & & & & $\sqrt{ }$ & & 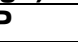 & 1 & $\mathrm{~K}$ \\
\hline \multicolumn{2}{|c|}{ Seasons } & $1^{\mathrm{st}}$ & $2^{\text {nd }}$ & $1^{\mathrm{st}}$ & $2^{\text {nd }}$ & $1^{\text {st }}$ & $2^{\text {nd }}$ & $1^{\text {st }}$ & $2^{\text {nd }}$ & $1^{\mathrm{st}}$ & $2^{\text {nd }}$ \\
\hline \multirow{5}{*}{ Mineral- N } & 0 & 8.09 & 8.08 & 10.53 & 9.43 & 38.54 & 39.76 & 3.52 & 3.61 & 193 & 195 \\
\hline & 50 & 8.06 & 8.04 & 8.14 & 7.98 & 41.20 & 41.62 & 3.61 & 3.74 & 197 & 198 \\
\hline & 75 & 8.02 & 8.01 & 7.95 & 6.88 & 42.59 & 42.66 & 3.74 & 3.77 & 203 & 207 \\
\hline & 100 & 8.00 & 8.00 & 7.53 & 6.72 & 43.52 & 44.12 & 3.81 & 3.83 & 206 & 213 \\
\hline & Mean & --- & $-\cdots$ & 8.54 & 7.75 & 41.46 & 42.04 & 3.67 & 3.74 & 200 & 203 \\
\hline \multirow{5}{*}{$\begin{array}{l}\text { Compost + } \\
\text { Mineral- N }\end{array}$} & 0 & 8.07 & 8.05 & 9.88 & 8.97 & 40.82 & 40.93 & 3.54 & 3.58 & 196 & 196 \\
\hline & 50 & 8.02 & 8.01 & 7.83 & 6.44 & 42.19 & 42.53 & 3.88 & 3.92 & 203 & 207 \\
\hline & 75 & 8.00 & 7.99 & 7.66 & 6.23 & 43.18 & 43.68 & 4.03 & 4.05 & 209 & 214 \\
\hline & 100 & 7.98 & 7.96 & 6.83 & 5.14 & 44.03 & 44.15 & 4.07 & 4.09 & 212 & 216 \\
\hline & Mean & --- & --- & 8.05 & 6.70 & 42.56 & 42.82 & 3.88 & 3.91 & 205 & 208 \\
\hline \multirow{5}{*}{$\begin{array}{l}\text { Bio- } \\
\text { fertilizer } \\
\text { Mineral- N }\end{array}$} & 0 & 8.06 & 8.04 & 9.83 & 8.65 & 40.68 & 40.63 & 3.57 & 3.62 & 194 & 198 \\
\hline & 50 & 8.03 & 8.02 & 7.55 & 6.25 & 42.29 & 42.33 & 3.76 & 3.84 & 201 & 204 \\
\hline & 75 & 8.01 & 8.00 & 7.43 & 6.10 & 43.96 & 44.27 & 3.84 & 3.88 & 207 & 210 \\
\hline & 100 & 8.00 & 7.98 & 6.75 & 5.22 & 43.58 & 43.69 & 3.93 & 3.97 & 213 & 215 \\
\hline & Mean & --- & ----- & 7.89 & 6.55 & 42.63 & 42.73 & 3.78 & 3.83 & 204 & 207 \\
\hline \multicolumn{2}{|l|}{ Mean 0} & --- & ---- & 10.08 & 8.02 & 40.01 & 40.44 & 3.54 & 3.60 & 194 & 196 \\
\hline \multicolumn{2}{|l|}{ Mean 50} & ----- & ---- & 7.84 & 6.89 & 41.89 & 42.16 & 3.75 & 3.83 & 200 & 203 \\
\hline \multicolumn{2}{|l|}{ Mean 75} & $-\cdots$ & ---- & 7.68 & 6.40 & 43.24 & 43.54 & 3.87 & 3.90 & 206 & 210 \\
\hline \multicolumn{2}{|c|}{ Mean 100} & ---- & +-- & 7.04 & 5.69 & 43.71 & 43.99 & 3.94 & 3.96 & 210 & 215 \\
\hline \multicolumn{2}{|c|}{ General mean } & ----- & 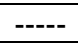 & 8.16 & 7.00 & 42.21 & 42.53 & 3.78 & 3.82 & 202 & 215 \\
\hline \multicolumn{2}{|c|}{ LSD. $5 \%$ fertilizer } & ---- & $\begin{array}{ll}---- \\
\end{array}$ & ns & ns & ns & ns & ns & ns & ns & ns \\
\hline \multicolumn{2}{|c|}{ LSD.5 \% rate } & ----- & ----- & 0.95 & 0.86 & 0.88 & 0.68 & ns & ns & 1.14 & 0.63 \\
\hline \multicolumn{2}{|c|}{ Interaction } & ---- & ----- & $\star \star *$ & $\star \star$ & $\star \star *$ & ** & $\star \star *$ & ** & $\star \star$ & $\star \star *$ \\
\hline
\end{tabular}

\section{Available macronutrient contents in soil:}

Results in Table (3) show significant increases in available $\mathrm{N}$ and $\mathrm{K}$ contents in soil of both two seasons while the $\mathrm{P}$ content in soil was not significantly affected by different rates of the applied mineral nitrogen fertilizer. The application of fertilizers on available contents of $\mathrm{N}, \mathrm{P}$ and $\mathrm{K}$ in soil after harvest did not show a significant effect. The interaction between compost or bio-fertilizers and different $\mathrm{N}$ rates showed significantly effect on availability of $\mathrm{N}, \mathrm{P}$ and $\mathrm{K}$ contents in soil in both seasons. According to the relative increases of soil available $\mathrm{N}$ content after sugar beet harvesting, the used fertilization treatment can be arranged as the following descending order: bio-fertilizer $>$ compost $>$ mineral $\mathrm{N}$. The corresponding descending order for $\mathrm{P}$ and $\mathrm{K}$ was Compost $>$ bio-fertilizer $>$ mineral $\mathrm{N}$. These results are in agreement with those of Kavitha and Subramanian (2007) who reported that the available soil $\mathrm{N}$ content was higher in soil treated with bio-fertilizer in combination with mineral fertilizer. The available $\mathrm{P}$ and $\mathrm{K}$ in the soil also increased with increasing compost application. Rashed (2006) found that the 
soil content of available $\mathrm{N}$ declined at highest rate of the mineral nitrogen fertilization i.e. $100 \mathrm{~kg} \mathrm{~N} \mathrm{fed}^{-1}$. Rifat et al. (2010) reported that PGPR as a bio-fertilizer helps in fixing $\mathrm{N}_{2}$, solubilizing mineral phosphates and other nutrients as well as enhancing tolerance to stress.

Availability of micronutrients in the studied soil:

Table (4) show that the soil available micronutrient contents (Fe, Mn, and $\mathrm{Zn}$ ) was increased due to the applied treatments and increases were more pronounced with compost $+100 \mathrm{~kg} \mathrm{~N}$ fertilizer than the other treatments in both seasons. These increases might be attribute to potential decrease due to release of organic acids up on decomposition of the applied organic matter on one hand beside of the organic matter itself is considered a source of $\mathrm{Fe}$, $\mathrm{Mn}$ and $\mathrm{Zn}$. Table (4) show also that Fe, $\mathrm{Mn}$ and $\mathrm{Zn}$ tended to increase in soil with increasing rate of the applied mineral nitrogen combined with compost or bio-fertilizer. These results are in agreement with those of Abdel Aal, et al. (2003) who found that the application of organic materials caused a substantial increase in Fe, $\mathrm{Mn}$ and $\mathrm{Zn}$ in soil. Shaban et al (2012) indicated that, $\mathrm{Fe}, \mathrm{Mn}$ and $\mathrm{Zn}$ tended to increase in soil with increasing rate of mineral $\mathrm{N}$ fertilizer in combination with organic and bio-fertilizer.

Table (4). Available Micronutrients contents in soil in the studied soil after harvesting of the sugar beat.

\begin{tabular}{|c|c|c|c|c|c|c|c|}
\hline \multirow{2}{*}{ Treatment } & \multirow{2}{*}{$\begin{array}{l}\text { Rate of } \\
\qquad \\
\text { kgfed- }^{1}\end{array}$} & \multicolumn{6}{|c|}{$\begin{array}{l}\text { Available micronutrients } \\
\qquad\left(\mathrm{mg} \mathrm{kg}^{-1}\right)\end{array}$} \\
\hline & & \multicolumn{2}{|c|}{$\mathrm{Fe}$} & \multicolumn{2}{|c|}{ Mn } & \multicolumn{2}{|c|}{$\mathrm{Zn}$} \\
\hline \multicolumn{2}{|l|}{ Seasons } & $1^{\mathrm{st}}$ & $2^{\text {nd }}$ & $1^{\mathrm{st}}$ & $2^{\text {nd }}$ & $1^{\text {st }}$ & $2^{\text {nd }}$ \\
\hline \multirow{5}{*}{ Mineral- N } & 0 & 2.26 & 2.27 & 1.56 & 1.59 & 0.77 & 0.80 \\
\hline & 50 & 2.38 & 2.40 & 1.64 & 1.66 & 0.82 & 0.85 \\
\hline & 75 & 2.44 & 2.47 & 1.69 & 1.70 & 0.89 & 0.94 \\
\hline & 100 & 2.48 & 2.51 & 1.72 & 1.74 & 0.95 & 0.98 \\
\hline & Mean & 2.39 & 2.41 & 1.65 & 1.67 & 0.86 & 0.89 \\
\hline \multirow{5}{*}{ Compost + Mineral- N } & 0 & 2.28 & 2.32 & 1.59 & 1.61 & 0.82 & 0.87 \\
\hline & 50 & 2.40 & 2.44 & 1.72 & 1.75 & 0.88 & 0.93 \\
\hline & 75 & 2.62 & 2.66 & 1.77 & 1.80 & 0.93 & 0.97 \\
\hline & 100 & 2.68 & 2.72 & 1.82 & 1.85 & 0.97 & 1.02 \\
\hline & Mean & 2.50 & 2.54 & 1.73 & 1.75 & 0.90 & 0.95 \\
\hline \multirow{5}{*}{$\begin{array}{l}\text { Bio-fertilizer+ Mineral- } \\
\mathrm{N}\end{array}$} & 0 & 2.27 & 2.31 & 1.58 & 1.60 & 0.81 & 0.84 \\
\hline & 50 & 2.39 & 2.42 & 1.70 & 1.73 & 0.87 & 0.89 \\
\hline & 75 & 2.55 & 2.57 & 1.75 & 1.76 & 0.92 & 0.97 \\
\hline & 100 & 2.60 & 2.63 & 1.78 & 1.80 & 0.95 & 0.98 \\
\hline & Mean & 2.45 & 2.48 & 1.70 & 1.72 & 0.89 & 0.92 \\
\hline \multicolumn{2}{|l|}{ Mean 0} & 2.27 & 2.30 & 1.58 & 1.60 & 0.80 & 0.84 \\
\hline \multicolumn{2}{|l|}{ Mean 50} & 2.39 & 2.42 & 1.69 & 1.71 & 0.86 & 0.89 \\
\hline \multicolumn{2}{|l|}{ Mean 75} & 2.54 & 2.57 & 1.74 & 1.75 & 0.91 & 0.96 \\
\hline \multicolumn{2}{|l|}{ Mean 100} & 2.59 & 2.62 & 1.77 & 1.80 & 0.96 & 0.99 \\
\hline \multicolumn{2}{|l|}{ General mean } & 2.45 & 2.48 & 1.69 & 1.71 & 0.88 & 0.92 \\
\hline \multicolumn{2}{|l|}{ LSD. $5 \%$ fertilizer } & ns & ns & ns & ns & ns & ns \\
\hline \multicolumn{2}{|l|}{ LSD.5 \% rate } & ns & ns & ns & 0.052 & 0.022 & 0.044 \\
\hline \multicolumn{2}{|l|}{ Interaction } & ns & ns & ns & $\star \star \star \star ~$ & $\star * \star *$ & $\star \star$ \\
\hline
\end{tabular}


In general, the positive effects of the used different mineral nitrogen fertilizer rates, compost and bio-fertilizer on available Fe, Mn and $\mathrm{Zn}$ could be arranged in following descending order : Compost $>$ bio-fertilizer $>$ mineral $\mathrm{N}$ fertilizer.

It is worthy to mention that the contents of the available Fe and $\mathrm{Mn}$ are within the sufficient limits while the content of $Z n$ is in critical limit according to (FAO, 1992).

\section{Sugar beet yield:}

Effect of mineral nitrogen fertilizer; compost and bio-fertilizer on yield and yield components are presented in Table (5) which shows that weight of fresh roots $\left(\mathrm{Mg} \mathrm{fed}^{-1}\right)$ significantly increased as affected by mineral nitrogen, compost and bio-fertilizer and the increases more obvious with increasing rate of the mineral $\mathrm{N}$ in both seasons. The effects rate of the applied mineral $\mathrm{N}$ on dry root $\left(\mathrm{Mg} \mathrm{fed}^{-1}\right)$, sugar yield $\left(\mathrm{Mg} \mathrm{fed}^{-1}\right)$, purity (\%) and sucrose (\%) were significant in both studied seasons. Also, the interaction between rate and each of compost and bio-fertilizer on fresh root, dry root sugar yield and purity (\%) were significant in both seasons. On the other hand, the application of the used fertilizers did not affect significantly the sugar yield, TSS (\%), purity (\%) and sucrose (\%) in both seasons. Concerning the purity sugar (\%) and sucrose (\%), they were increased with soil treated by bio-fertilizer combined with $50 \mathrm{~kg} \mathrm{~N}$ fertilizer compared with other treatments. These results are in agreement with Bahman et al (2013) who found that increasing the nitrogen fertilizer caused a meaningful reduction in the sucrose (\%) and the purity of sugar (\%), while the application of biological fertilizer showed an increase in root yield, sucrose and purity of sugar (\%). Kandil et al., (2004) reported that seed treatment of sugar beet by biological basis fertilizer of Rhizobacterium caused significant increases in dry and fresh root weight, leaf area index, crop growth rate and the rate of photosynthesis. Bacterial $(R$. radiobacter) are plant growth promoting rhizobacteria and some are endophytes which can produce phytohormones, siderphores, solubilize sparingly soluble organic and inorganic phosphates, also might influenced cytokinins and IAA hormone contents. Rhizobium radiobcter has an effect on promoting plant growth and increasing pathogen resistance against powdery mildew and can colonize the roots of many non-legumes (Sessitsch et al., 2002). (Ben Romdhane et al., (2005). and Sinha et al., (2014) suggested that bio-fertilizers keep the soil environment rich in all kinds of micro- and macronutrients via nitrogen fixation, phosphate and potassium solubalization or mineralization, release of plant growth regulating substances, production of antibiotics and biodegradation of organic matter in the soil. Bio-fertilizer inoculation positively affected productivity and physiological criteria as well as salinity tolerance of the tested plants (Tawfik et a.I (2011).

\section{Macronutrients concentrations in root:}

Data presented in Table (6) show that application of compost, biofertilizer alone or in combined with mineral nitrogen affected significantly effect on $\mathrm{N}$ concentration in roots but did not show such an effect on $\mathrm{P}$ and $\mathrm{K}$ in both seasons. 
Table (5). Yield and yield components of sugar beat.

\begin{tabular}{|c|c|c|c|c|c|c|c|c|c|c|c|c|c|}
\hline Treatment & $\begin{array}{c}\text { Rate of } \\
\mathrm{N} \\
\text { kgfed- }^{-1}\end{array}$ & \multicolumn{2}{|c|}{$\begin{array}{l}\text { Root fresh } \\
\text { weight } \\
\left.{ }^{*} \text { Mg fed }^{-1}\right)\end{array}$} & \multicolumn{2}{|c|}{$\begin{array}{c}\text { Root dry } \\
\text { weight } \\
\left(\text { Mg fed }^{-1}\right)\end{array}$} & \multicolumn{2}{|c|}{$\begin{array}{c}\text { Sugar } \\
\text { yield } \\
\left(\text { Mg fed }^{-1}\right)\end{array}$} & \multicolumn{2}{|c|}{$\begin{array}{c}{ }^{\star \star} \text { TSS } \\
(\%)\end{array}$} & \multicolumn{2}{|c|}{$\begin{array}{c}\text { Purity } \\
(\%)\end{array}$} & \multicolumn{2}{|c|}{$\begin{array}{c}\text { Sucrose } \\
(\%)\end{array}$} \\
\hline \multicolumn{2}{|c|}{ Seasons } & $1^{\mathrm{st}}$ & $2^{\text {nd }}$ & $1^{\text {st }}$ & $2^{\text {nd }}$ & $1^{\mathrm{st}}$ & $2^{\text {nd }}$ & $1^{\text {st }}$ & $2^{\text {nd }}$ & $1^{\text {st }}$ & $2^{\text {nd }}$ & $1^{\mathrm{st}}$ & $2^{\text {nd }}$ \\
\hline \multirow{5}{*}{ Mineral $-\mathrm{N}$} & 0 & 2.59 & 2.75 & 0.695 & 0.703 & 0.39 & 0.41 & 22.18 & 22.36 & 73.80 & 73.96 & 14.96 & 15.21 \\
\hline & 50 & 8.93 & 9.14 & 1.960 & 2.160 & 1.36 & 1.41 & 23.30 & 23.54 & 79.63 & 81.25 & 15.27 & 5.49 \\
\hline & 75 & 9.47 & 10.22 & 2.495 & 2.522 & 1.52 & 1.66 & 23.71 & 23.85 & 83.24 & 84.61 & 16.10 & 16.23 \\
\hline & 100 & 11.83 & 12.13 & 2.837 & 2.850 & 1.98 & 2.04 & \begin{tabular}{|l|}
23.83 \\
\end{tabular} & 23.91 & 85.19 & 85.29 & 16.75 & 16.82 \\
\hline & Mean & 8.21 & 8.56 & 2.00 & 2.06 & 1.31 & 1.38 & 23.26 & 23.42 & 80.47 & 81.28 & 15.77 & 15.94 \\
\hline \multirow{5}{*}{$\begin{array}{l}\text { Compost + } \\
\text { Mineral- N }\end{array}$} & 0 & 3.74 & 3.85 & 0.846 & 0.863 & 0.63 & 0.65 & 22.20 & 22.83 & 82.16 & 83.07 & 16.82 & 16.95 \\
\hline & 50 & 14.67 & 14.96 & 3.286 & 3.318 & 2.74 & 2.80 & 23.65 & 23.89 & 85.72 & 86.41 & 18.66 & 18.73 \\
\hline & 75 & 18.52 & 19.14 & 3.729 & 3.749 & 3.48 & 3.60 & 23.86 & 23.92 & 88.39 & 89.76 & 18.79 & 18.83 \\
\hline & 100 & 22.41 & 23.08 & 4.533 & 4.660 & 4.23 & 4.37 & 24.37 & 23.94 & 92.18 & 92.45 & 18.88 & 18.94 \\
\hline & Mean & 14.84 & 15.26 & 3.10 & 3.15 & 2.77 & 2.86 & 23.52 & 23.65 & 87.11 & 87.92 & 18.29 & 18.36 \\
\hline \multirow{5}{*}{$\begin{array}{c}\text { Bio- } \\
\text { fertilizer+ } \\
\text { Mineral- N }\end{array}$} & 0 & 3.70 & 3.88 & 0.839 & 0.845 & 0.62 & 0.66 & 22.81 & 22.96 & 88.39 & 89.13 & 16.92 & 17.02 \\
\hline & 50 & 14.32 & 14.55 & 3.349 & 3.369 & 2.76 & 2.84 & 23.78 & 23.89 & 95.47 & 97.19 & 19.28 & 19.55 \\
\hline & 75 & 21.19 & 22.59 & 4.120 & 4.231 & 3.95 & 4.26 & 25.17 & 25.22 & 92.78 & 93.22 & 18.66 & 18.88 \\
\hline & 100 & 20.93 & 21.16 & 4.115 & 4.126 & 3.87 & 4.01 & 23.93 & 23.98 & 91.96 & 92.59 & 18.53 & 18.74 \\
\hline & Mean & 15.04 & 15.55 & 3.11 & 3.14 & 2.80 & 2.94 & 23.92 & 24.01 & 92.15 & 93.03 & 18.35 & 18.55 \\
\hline \multicolumn{2}{|c|}{ Mean 0} & 3.34 & 3.49 & 0.79 & 0.80 & 0.55 & 0.57 & 22.40 & 22.72 & 81.45 & 82.05 & 16.23 & 16.39 \\
\hline \multicolumn{2}{|c|}{ Mean 50} & 12.64 & 12.88 & 2.87 & 2.95 & 2.29 & 2.35 & 23.58 & 23.77 & 86.94 & 88.28 & 17.74 & 17.92 \\
\hline \multicolumn{2}{|c|}{ Mean 75} & 16.39 & 17.32 & 3.45 & 3.50 & 2.98 & 3.17 & 24.25 & 24.33 & 88.14 & 89.20 & 17.85 & 17.98 \\
\hline \multicolumn{2}{|c|}{ Mean 100} & 18.39 & 18.79 & 3.83 & 3.88 & 3.36 & 3.47 & 24.04 & 23.94 & 89.78 & 90.11 & 18.05 & 18.17 \\
\hline \multicolumn{2}{|c|}{ General mean } & 12.70 & 13.12 & 2.74 & 2.78 & 2.29 & 2.39 & 23.57 & 23.69 & 86.58 & 87.41 & 17.47 & 17.62 \\
\hline \multicolumn{2}{|c|}{ LSD. $5 \%$ fertilizer } & 2.420 & 1.087 & $\mathrm{~ns}$ & 0.230 & $\mathrm{~ns}$ & $\mathrm{~ns}$ & ns & ns & Ns & $\mathrm{ns}$ & $\mathrm{ns}$ & ns \\
\hline \multicolumn{2}{|c|}{ LSD. $5 \%$ rate } & 4.560 & 1.865 & 0.579 & 0.621 & 1.140 & 0.840 & ns & ns & 2.73 & 3.70 & 2.216 & 1.860 \\
\hline \multicolumn{2}{|c|}{ Interaction } & $\star \star \star *$ & 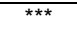 & ** & ** & $* * *$ & ** & $* * *$ & ns & $* \star * *$ & ** & $\mathrm{ns}$ & ns \\
\hline
\end{tabular}

${ }^{\star} \mathrm{Mg}=$ ton $=1000 \mathrm{~kg}$

${ }^{*}$ TSS Total Soluble Solids

Table (6). Macro and micronutrient concentrations in root of sugar beet.

\begin{tabular}{|c|c|c|c|c|c|c|c|c|c|c|c|c|c|}
\hline \multirow[t]{2}{*}{ Treatment } & \multirow{3}{*}{$\begin{array}{l}\text { Rate of } \\
\mathbf{N} \\
\text { kgfed-1 }\end{array}$} & \multicolumn{6}{|c|}{$\begin{array}{c}\text { Macronutrient concentration in } \\
\text { root } \\
(\%)\end{array}$} & \multicolumn{6}{|c|}{$\begin{array}{c}\text { Micronutrient concentration in } \\
\text { root } \\
\left(\mathrm{mg} \mathrm{kg}^{-1}\right)\end{array}$} \\
\hline & & \multicolumn{2}{|c|}{$\mathbf{N}$} & \multicolumn{2}{|c|}{ D } & \multicolumn{2}{|c|}{$\mathbf{K}$} & \multicolumn{2}{|c|}{$\mathrm{Fe}$} & \multicolumn{2}{|c|}{ Mn } & \multicolumn{2}{|c|}{$\mathbf{Z n}$} \\
\hline Seasons & & $1^{\mathrm{st}}$ & $2^{\text {nd }}$ & $1^{\mathrm{st}}$ & $2^{\text {nd }}$ & $1^{\mathrm{st}}$ & $2^{\text {nd }}$ & $1^{\mathrm{st}}$ & $2^{\text {nd }}$ & $1^{\mathrm{st}}$ & $2^{\text {nd }}$ & $1^{\mathrm{st}}$ & $2^{\text {nd }}$ \\
\hline \multirow{5}{*}{ Mineral - $\mathrm{N}$} & 0 & 0.89 & 0.85 & 0.11 & 0.14 & 1.07 & 1.08 & 45.25 & 45.36 & 29.88 & 329.91 & 14.85 & 14.88 \\
\hline & 50 & 0.92 & 0.94 & 0.15 & 0.17 & 1.12 & 1.14 & 45.69 & 45.75 & 31.54 & $\begin{array}{l}41.66 \\
\end{array}$ & 16.52 & 16.58 \\
\hline & 75 & 0.97 & 0.99 & 0.1 & 0.2 & 1.18 & 1.20 & 45.88 & 45.93 & & 31.72 & 16.66 & 16.72 \\
\hline & 100 & 1.02 & 1.03 & & & 1.23 & 1.25 & 46.10 & & & & & \\
\hline & Mean & 0.95 & 0. & & & & 1. & 45.73 & & & 31.29 & & 6.26 \\
\hline \multirow{5}{*}{$\begin{array}{l}\text { Compost } \\
\text { Mineral- N }\end{array}$} & 0 & .92 & & & & & & 45.63 & & & & & \\
\hline & 50 & 0.97 & 0.99 & 0.1 & & 8 & 1.09 & 46.23 & 38 & 31.66 & 31.75 & 16.83 & 6.88 \\
\hline & 75 & 1.06 & 1.08 & 0.22 & 0.2 & 1.30 & 1.32 & 46.39 & 46.45 & 32.12 & 32.15 & 17.93 & 17.96 \\
\hline & 100 & 1.12 & 1.14 & 0.25 & 0.2 & 1.32 & 1.34 & 47.22 & 47.35 & 32.18 & 32.20 & 17.98 & 18.00 \\
\hline & Mean & 1.02 & 1.04 & 0.20 & 0.1 & 1.18 & 1.20 & 46.37 & 46.46 & 31.70 & 31.76 & 17.11 & 17.15 \\
\hline \multirow{5}{*}{$\begin{array}{l}\text { Bio-fertilizer+ } \\
\text { Mineral- N }\end{array}$} & 0 & 0.90 & 0.95 & 0.12 & 0.1 & 1.06 & 1.08 & 45.67 & 45.88 & 30.91 & 30.95 & 15.69 & 15.75 \\
\hline & & 1.03 & 1.08 & & & & 1.15 & 46.58 & & 31.72 & 31.88 & 16.55 & 16.63 \\
\hline & 75 & 1.07 & 1.13 & 0.2 & & 1.1 & 1.22 & 47.38 & 49.14 & 31.88 & 31.96 & 17.83 & 17.85 \\
\hline & 100 & 0.98 & 1.05 & 0.2 & 0.28 & 1.25 & 1.29 & 47.39 & 49.20 & 32.14 & $\begin{array}{l}432.20 \\
\end{array}$ & 17.92 & 17.96 \\
\hline & Mean & 1.00 & 1.05 & 0.2 & 0.2 & 1.16 & 1.19 & 46.76 & 47.73 & 31.66 & 31.75 & 17.00 & 17.05 \\
\hline \multicolumn{2}{|l|}{ Mean 0} & 0.90 & 0.92 & 0.12 & 0.15 & 1.05 & 1.07 & 45.52 & 45.63 & 30.55 & 530.60 & 15.42 & 15.46 \\
\hline \multicolumn{2}{|l|}{ Mean 50} & 0.97 & 1.00 & 0.17 & 0.20 & 1.11 & 1.13 & 46.17 & 46.27 & 31.64 & $\begin{array}{l}431.76 \\
\end{array}$ & 16.63 & 16.70 \\
\hline \multicolumn{2}{|l|}{ Mean 75} & 1.03 & 1.07 & 0.21 & 0.22 & 1.22 & 1.25 & 46.55 & 47.17 & 31.88 & 31.94 & 17.47 & 17.51 \\
\hline \multicolumn{2}{|l|}{ Mean 100} & 1.04 & 1.07 & 0.2 & 0.25 & 1.27 & 1.29 & 46.90 & 47.58 & 32.01 & 32.08 & 17.57 & 17.60 \\
\hline \multicolumn{2}{|c|}{ General mean } & 0.99 & 1.01 & 0.19 & 0.20 & 1.16 & 1.19 & 46.29 & 46.67 & 31.52 & 31.60 & 16.77 & 16.82 \\
\hline \multicolumn{2}{|c|}{ LSD.5 \% fertilizer } & 0.022 & 0.030 & & & $\mathrm{~ns}$ & ns & ns & ns & ns & ns & ns & ns \\
\hline \multicolumn{2}{|c|}{ LSD.5\% rate } & 0.041 & 0.071 & 0.012 & 0.046 & ns & $\mathrm{ns}$ & ns & ns & ns & $\mathrm{ns}$ & ns & $\mathrm{ns}$ \\
\hline \multicolumn{2}{|l|}{ Interaction } & $\star \star \star$ & $\star \star *$ & $\star \star$ & 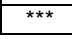 & ** & ** & ns & ns & ns & ns & ns & ns \\
\hline
\end{tabular}


Increasing rate of the mineral $\mathrm{N}$ significantly increased $\mathrm{N}$ and $\mathrm{P}$ concentrations in roots in both seasons, but the effect of different rate of fertilizers application on $\mathrm{K}$ was not significant in both seasons. Also, the interaction of compost or bio-fertilizer in combination with different rates of $\mathrm{N}$ significantly effected $\mathrm{N}, \mathrm{P}$ and $\mathrm{K}$ concentrations in roots in both seasons, but the effect of rate of fertilizer application on $\mathrm{K}$ was not significant in both seasons. While, the interaction between compost or bio-fertilizer in combination with different rates of $\mathrm{N}$ significantly affected $\mathrm{N}, \mathrm{P}$ and $\mathrm{K}$ concentrations in roots in both seasons.

These results are in agreement with those of ElKoca et al., (2008) who indicated that inoculation with the bio-fertilizer (PGPR) strains increased $\mathrm{N}, \mathrm{P}$ and $\mathrm{K}$ content in root. Generally, the increases occurred in macronutrient concentrations in roots of sugar beet may be due to decrease in soil pH, soil salinity and increase of the activity of microorganisms in soil due to the aforementioned treatments

Micronutrient concentrations in root of sugar beet:

Table (6) show that applying compost, bio-fertilizer and mineral $\mathrm{N}$ fertilizer caused significant increases in concentrations of Fe, $\mathrm{Mn}$ and $\mathrm{Zn}$ in root whoever, the increases were more pronounced by increasing rate of the applied mineral $\mathrm{N}$ fertilizer. These results are in agreement with those obtained by Adewole and Ilesanmi (2011) who found that the organic fertilizer may have enhanced the availability, mobility and uptake of these nutrients in the roots. El-Shaikh and Mohammed (2009) went to the same results and reported that bio-fertilizer enhanced the uptake of micronutrients, such as $\mathrm{Zn}$, $\mathrm{Fe}, \mathrm{Mn}$ and $\mathrm{Cu}$.

\section{CONCLUSION}

Bio-fertilizer and compost application in agriculture will have greater impact on organic agriculture and also to control the environmental pollution, soil health improvement. So, using a mixture of selected effective microorganisms active in nitrogen fixation, hormonal and enzyme production in combination with compost can partially meet the nutrient requirements of sugar beet production under saline soil conditions. However, sugar beet would have to develop growth, which responds to the integrated use of compost and bio-fertilizer inoculation to reduce the dose of mineral nitrogen fertilizers needed. As a result, biological fertilizer, with a lower cost, had a more usage of the soil. 


\section{REFERENCES}

Abdel Aal, S.I., Abdel M.A. Hamid, S.A. Ismaiel, A. Abd El-Fattah and A.S. Taalab, (2003). Effect of organic farming practice on nutrition, availability and wheat yield grown on torripsamments. Egypt. J. Soil Sci., 43(1): 47-62.

Abd El-All, A.A.; M.H. El-Sherif, H. Sh. Shehata, and R.M. El-Shahat, (2013). Efficiency use of nitrogen, biofertilizers and compost biostraw on rice production under saline soil. J. of Appl. Sci. Res. 9 (6): 1604- 1611.

Adewole, M. B. and A. O. Ilesanmi, (2011). Effect of soil amendments on the nutritional quality of okra (Abelmoschus esculentus L. Moench). J. Soil Sci. Plant Nutr. 11, (3): $45-55$.

Ali, A. A. ; A. Sh. Khaled, and M. S. Abdel-Hamid, (2014). L-Tryptophan and thiamine hydrochloride as vital factors of the indole acetic acid and siderophores produced by rhizobium leguminosarum bv. Viceae and their reflection on faba bean growth yield and some properties under saline soil. Inter. J. of Sci. Basic and Appl. Res. 15 (1): 107- 122.

Aguilera, J. ; P. P Motavalli,. ; M. A. Gonzales, and C. Valdivia, (2012). Initial and residual effects of organic and inorganic amendments on soil properties in a potato-based cropping system in the biolivian Andean highlands. American J. of Experimental Agriculture. 2 (4): 641- 666.

Arafa, R. A.M.; F. B. AbdEl-Ghany, M. N. Sidkey, and M. M. ElShazly, (2009). The beneficial use of biofertilizers on growth and yield of wheat plants grown on sandy soil with or without nitrogen fertilization .Egyptian J. of Biotechnology, 32: 127-146.

Bahman , J. ; G. Reza, Z. F. Ahmad, and Z. G Ali,. (2013). Impact of crop density and soil fertilization on sugar beet. Inter . J. Agric. and Crop Sci. 5 (24): 2991- 2999.

Bassal, S.A.A. ; A.A. Zohry, and K.A. Douby, (2001). Effect of row and hill spacings and bio-mineral $\mathrm{N}$-fertilization rates on sugar beet productivity. J. Agric. Sci., Mansoura Univ., 26(9): 5217-5226.

Ben Romdhane, S.; H. Nasr, R. Samba, M. Neyra, and M. H. Ghorbal, (2005). Diversity of acacia tortils rhizobia revealed by PCR/ RFLP on cursed root nodules in Tunisia. An . Microbiol. 55 (4): 249- 258.

Brunner , P. H. and H. R. Wasmer , (1978) Methods of analysis of sewage sludge solid wastes and compost. W.H.O. International Reference Center for Wastes Disposal (H-8600), Dulendrof Switzerland.

Black, C.A. (Ed) (1965)."Methods of Soil Analysis". Ser. Agron. No 9 Amer. Soc. Agron., Madison, Wisconsin.

Calderon, F.J.; G.W. McCarty, J.A. Van Kassel , and J.B. Reeves, (2004). Carbon and nitrogen dynamic during incubation of manured soil. Soil Sci. Soc. Amer J., 68: 1592-1599

Cottenie, A.; M. verloo, G.Velghe, and R.Cameriynck, (1982). "Chemical analysis of plant and soil." Laboratory of analytical and agrochemistry, State Univ., Ghent, Belgium. 
EL-Geddawy, I.H.; M. L. Saif and F.A. Abd EL-Latief, (2001). Hoeing and nitrogen fertilization with respect to quality, yield and yield components of some sugar beet varieties grown in Upper Egypt. J. Agric. Sci. Mansoura Univ., 26(8): 4647-4661.

Elkoca, E., F. Kantar, and F. Sahin, (2008). Influence of nitrogen fixing and phosphorus solubilizing bacteria on the nodulation, plant growth, and yield of chickpea. Journal of Plant Nutrition. (31): 157-171.

El-Shaikh, K. A. A.and M. S. Mohammed, (2009). Enhancing fresh and seed yield of okra and reducing chemical phosphorus fertilizer via using Vamy-corrhizaal inoculants. World Journal of Agricultural Sciences, 5 (S): 810-818.

FAO, (1992). Waste water treatment and use in agriculture. FAO Soils Bull. No.47, Rome

Fathy, M.F.A. and Kamal , K. A. (2009). Response of sugar beet plants to nitrogen and potassium fertilization in sandy calcareous soil. Intr. J. Agric . Biolo. 11 (6): $695-700$.

Guillaumes, E.; Carrasco, I. and Villar, J.M. (2006). Response of wheat to additional nitrogen fertilizer application after pig slurry on overfertilized soils, Agron. Sustain. Dev., 26:127-133.

Hachicha, S.; Chtourou, M.; Medhioub, K. and Ammar, E. (2006). Compost of poultry manure and olive mill wastes as an alternative fertilizer, Agron. Sustain. Dev., 26:135-142.

Helmy, A. M.; Abd El-Fatth, M. K. and Shaban, Kh. A. (2013). Nirtogen efficency in barely under saline- sodic conditions as affected by urea, compost and biofertilizer (Rhizobium radiobacter sp.). J. Soil and Agric. Eng. Mansoura Univ., 4(11): 1169 - 1189.

Kandil, A.A.; Badawi, M.A.; El-Moursy, S. A. and Abdou, U. A. (2004). Effect of planting dates, nitrogen levels and biofertilization treatments on 1: Growth attributes of sugar beet. Scientific journal of King faisal University (5) : 14 - 25.

Kavitha, R. and Subramaninan , P.c (2007). Effect of enriched municipal solid waste compost application on soil available macronutrients in rice field. J. Agronomy and Soil Sci., (53): $497-506$.

Le-Docte, A. (1927). Commercial determination of sugar beet root using the Sachr Le-Docta process. International Sugar J., 29: 488-492. (C.F. Sugar beet Nutrition, April, 1927 Applied Sciences Publishers LTD, London, A.P. Draycott).

Mohamed, S. A.; Seaf El-Yazal, S. A. and El-Sowfy, D. M. (2008). Improving maize grain yield and its quality grown on a newly reclaimed sandy soil by appling micronutrients, organic manure and biological inoculation. Res. J. Agric. and Biolog. Sci., 4 (5): 537 - 544.

Mousa, A.E., (2004). Increasing sugar beet productivity by using different nitrogen fertilizer sources and its time of addition. M. Sc. Thesis, Fac. Agric., Mansoura Univ.

Negm, M. A., Rafaat, M. D. and Estefnous, A. N. (2003). Impact of composted saw-dust and some nitrogenous sources on the production of squash and table beet crops grown on calcareous soil. Fayoum, J. Agric. and Dev., 17 (1): 116 - 137. 
Nasef, M.A.; Shaban, Kh. A. and Abd El-Hamide, A. F. (2009). Effect of compost, compost tea and bio-fertilizer application on some chemical soil properties and rice productivity under saline soil condition. J. Agric. Mansoura Univ. 34 (4): 2609- 2623.

Page, A.L; Miller, R.H. and Keeney, D.R. (1982) "Methods of chemical analysis". Part 2: Chemical and microbiological properties (Second Edition). American Society of Agronomy, Inc. and Sci., Soc. of America, Inc. Publishers, Madison, Wisconsin U.S.A.

Ramadan, B.S.H. ; Hassan, H.R. and Abdou, F.A. (2003). Effect of mineral and biofertilizers on photosynthetic pigments, root quality, yield components and anatomical structure of sugar beet (Beta vulgaris, L.) plants grown under reclaimed soils. J. Agric. Sci., Mansoura Univ., 28(7): 5139-5160.

Rashed, Sh. (2006). Effect of bio and organic fertilization on Zea mays. MSc. Thesis, Faculty of Agriculture Mansoura Univ. Egypt.

Rifat, H.; Safdar A.; Ummay, A.; Rabia, Kh. and Iftikhar, A. (2010). Soil beneficial bactria and their role in plant growth promotion. J. Ann Microbiol., 7: 117-137.

Sarwar, G.; Schmeisky, H.; Hussain, N. ; Muhammad, S. Ibrahim, M. and Safdar, E. (2008). Improvement of soil physical and chemical properties with compost application in rice-wheat cropping system. Pakistan. J. Bot, 40(1): 275-282

Selim, E. M.; El-Sirafy , Z.M. and Taha, A. A. (2010). Effect of irrigation methods and $\mathrm{N}$ - applications on the utilization of nitrogen by sugar beet grown under arid condition. Aust. J. Basic and Appli. Sci., 4 (7): $2114-$ 2124.

Sessitsh, A., J.G. howieson, X. Perret, H. Autoun and E. Martinez-Romero. 2002 Advances in Rhizobium research. Crit, Rev., plant sci.,21:323378.

Shaban, Kh. A. ; AbdEl-Kader, M. G. and Khalil, Z. M. (2012). Effect of soil amendments on soil fertility and sesame crop productivity under newly reclaimed soil conditions. J. Appl. Sci. Res. 8 (3): 1568- 1575.

Shaban, Kh. A. and Omar, M.N. (2006). Improvement of maize yield and some soil properties by using nitrogen mineral and PGPR group fertilization in newly cultivated saline soils. Egypt. J. Sci.,46(3):329-342.

Shaban, Kh. A. ; AbdEl-Kader, M. G. and El Khadrawy, S . M. (2011). Evaluation of organic farm and compost combined with urea fertilizers on fertility and maize productivity in newly reclaimed soils. Res. J. of Agric. and Biolog. Sci.,7(5): 388-397.

Sherif, M. I; Ibrahim, H. A. and Omar, A. M. (2012). Comparative study of the effect of some organic extract on sugar beet yield under saline conditions. Auste. J. Basic and Appli. Sci., 6(10): $664-674$.

Siam, H. S. ; Shaban, Kh. A. and Mahmoud, S. A. (2013). Evaluation of applying different mineral nitrogen sources on soil fertility and wheat productivity under saline soil conditions. J. Appli . Sci., Res. 9 (4) : 3146- 3156. 
Sinha R. K; Valani D.; Chauhan K. and Agarwal, S. (2014). Embarking on a second green revolution for sustainable agriculture by vermiculture biotechnology using earthworms: reviving the dreams of Sir Charles Darwin. Int. J. Agric. Health Saf, 1:50-64.

Snedecor, G.W. and W. G. Cochran , (1979). "Statistical Methods". $7^{\text {th }}$ ed . IOWA, State Univ. U.S.A.

Soltanpour, N. (1985). Use of ammonium bicarbonate- DTPA soil test to evaluate element availability and toxicity . Soil Sci . Plant Anal. ,16 (3) : $323-338$.

Tandon, H.L.S. (2000). Fertilizer organic manures wastes and bio-fertilizers components of integrated plant. Fertilizer Development and consultation organization 204- 204, A Bhanot Corner, 1-2 Pamposh Enclave New Delhi. 110048. India.

Tawfik, M.M.; Abd El-Lateef, E.M. ; Amany A. , Bahr A. and Hozayen, M. (2011). Prospect of biofertilizer inoculation for increasing saline irrigation efficiency. Res. J. Agric. and Biol. Sci., 7 (2): 182 - 189.

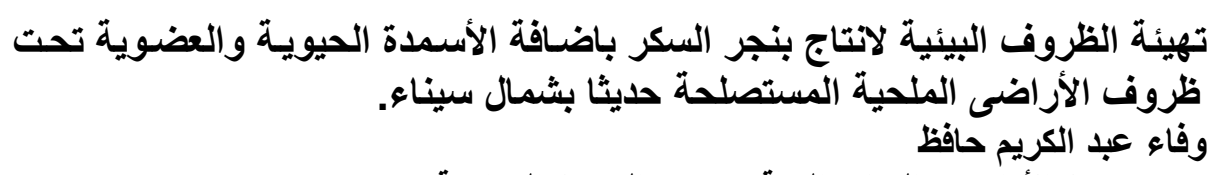

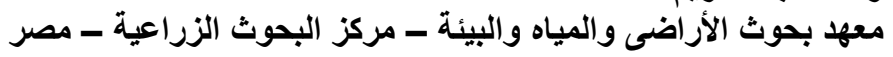

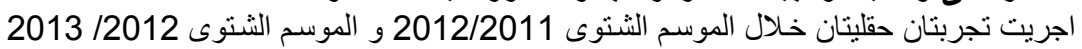

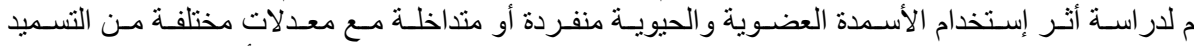

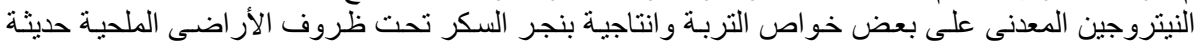

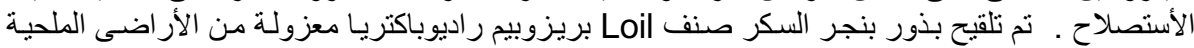

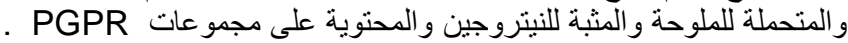

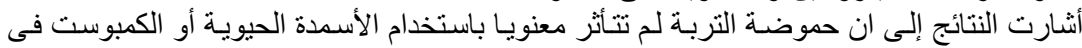

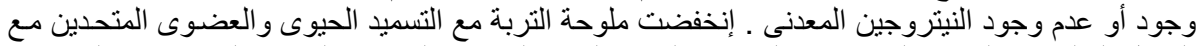

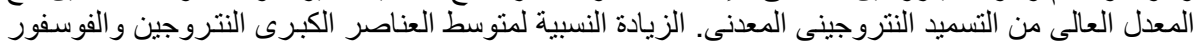

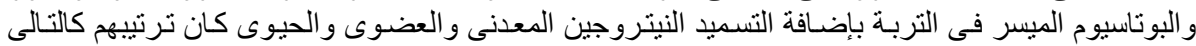

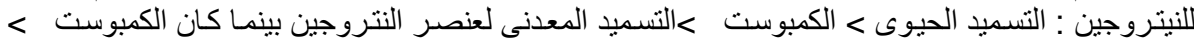

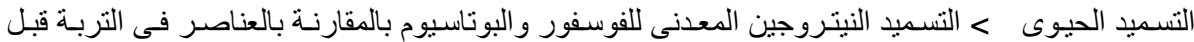

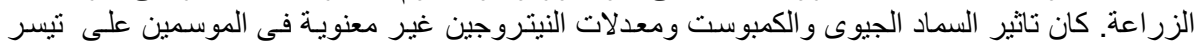

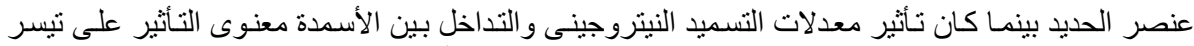

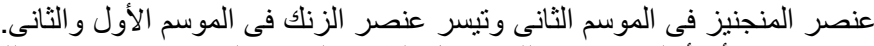

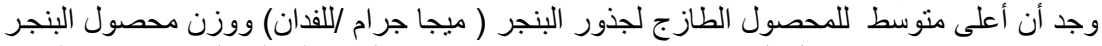

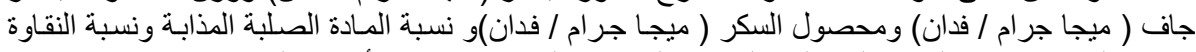

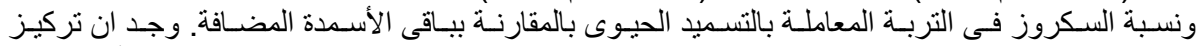

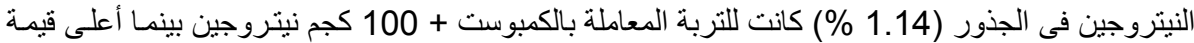

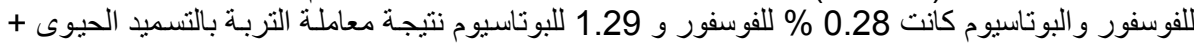

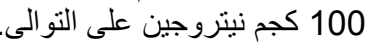
من ناحية اخرى وجد ان التسنيد التهيد الحيوى و الكمبوست و المعدنى لم يكن لهم تاثثير معنوى على تركيز

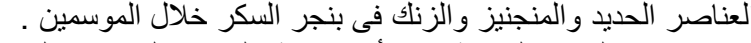

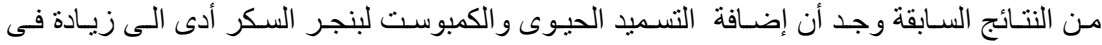

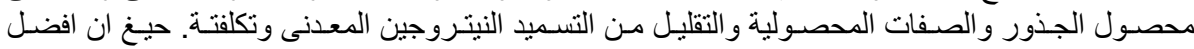
انتاجية لمحصول السكر كانت عند استخدام التسميد الحيوى مع 50 كجم من التسميد النتروجين المعندئ المعنى. 